\title{
PITEŞTI. THE DECOMPOSING OF THE SOUL BY RE-EDUCATION
}

\author{
Radu TASCOVICI*
}

\begin{abstract}
By this study we want to put forward the real aim of the gruesome process of 're-education' for the Romanian students who were kept in the Pitești prison. The aim was the destruction of their soul, in order to transform the human being into a machine bereft of liberty, going all lengths upon request of the communist agents, brought into Romania by the force of soviet tanks. That diabolical process was conceived as an unredeemable distortion of human mind and soul, performed by means of starving, by indescribable abasements, by bodily and spiritual tortures. At the end of this ordeal, the victim was to repudiate all his previous convictions, his family and his education. After all the tortures, each student was supposed to become a 'new man', in fact a yes-man, reborn in fear and terror. But this plan of the communist authorities failed, and the abnormality of this mechanism of spiritual destruction was abolished. The result of this process was that Romanian people and Romanian Orthodox Church acquired new martyrs, whose experience must be known by the new generations.
\end{abstract}

Keywords: communist regime, prison, process, 're-education', students.

\section{Introduction}

The Communist period started in Romania after the Second World War. After the $23^{\text {rd }}$ of August 1944, the situation of Romania was determined by the agreements between the three great victorious powers: the USA, Great Britain and the Soviet Union. On the $9^{\text {th }}$ of October 1944, in Moscow, Winston Churchill offered to Stalin 90\% control over Romania, in exchange for $90 \%$ control of Great Britain over Greece. There followed the Yalta Conference in February 1945, where the three

* PhD, Assistant Professor, Pitești University (Department of Theology), Pitești, Romania 
great powers leaders declared that 'in the freed Europe' they 'would jointly help' the liberated countries to organize 'free elections'. The Soviet Union interpreted this statement according to its own interests. The Control Allied Commission (Soviet, in fact) sustained all the Soviet orders which aimed at suppressing any forms of resistance in Romania. In this context the Communist Party was trying to gain the power. It started with aggressive attacks against the historical parties (National Liberal and National Rural) and against the Prime Minister Nicolae Rădescu, who was supported by the aforementioned parties. The Soviet representative Andrey Yanuarevich Vyshinsky imposed in February 1945 to king Mihai I, through an ultimatum, the forming of a pro-communist government, led by dr. Petru Groza. Great Britain and the American ambassadors finally accepted the Soviet command.

In January 1946, the Romanian Communist Party proposed to win the election with a percentage of 80 or even more. Thus, they used acts of violence, blackmails, murders, censoring the opposition mass media and numerous false votes. By all these means they got only $40 \%$ of the total number of votes. Despite the reality, they announced that the Block of the Democratic Parties (Romanian Communist Party and Hungarian Popular Union) would have got $91,30 \%$ of the votes, which was 378 mandates in the future Parliament. During the following period of time (1948-1965), the Parliament elections had to be always won only by the Romanian Communist Party, with more than 93\%, and during the Ceaușescu regime, with up to $99,9 \%$.

The last stage in transforming Romania into a communist state aimed at abolishing the Monarchy. On the $10^{\text {th }}$ of February 1947, in Paris, the peace treaty with Romania was signed. In an implicit way the Allies recognized the Communist Government of Petru Groza. A month after this event, the first wave of arresting started, thus inaugurating a brutal repression of all those who opposed the Communist Party. The victims were the principal members of the National Rural Party in every county. The second wave took place during the night of $4^{\text {th }}$ of May, five days after the Commons in London ratified the Peace Treaty with Romania. On the $5^{\text {th }}$ of June 1947, the USA also ratified the mentioned treaty; on the $29^{\text {th }}$ of July, the Communist Government decided the abolishing of the National Rural Party, their strongest opponent. The process of total communist control over Romania ended with three events: the condemnation of the 
ARS LITURGICA. From the Image of Glory to the Images of the Idols of Modernity

National Rural Party's leaders, based on false and fabricated accusations (including Iuliu Maniu and Ion Mihalache: both died in prison on $29^{\text {th }}$ of October and $11^{\text {th }}$ of November), removing the National Liberal Party from the Government and the forced abdication of KingMihai I on the $30^{\text {th }}$ of December. The same evening, the Popular Republic of Romania with a totalitarian regime and with the absolute political monopole of the Communist Party was proclaimed. And so, the pluralist democratic system, built by efforts throughout generations, was demolished ${ }^{1}$.

The year 1948 was dedicated by communists to strengthen their political power. On the $24^{\text {th }}$ of February, the National Assembly of Deputies was dissolved and elections were organized for a new legislative, The Great National Assembly, that was congregated on the $28^{\text {th }}$ of March. Before that, the Communist Party and the Social-Democrat Party coalesced, and on the $27^{\text {th }}$ of February a new Criminal Law was passed. On the $13^{\text {th }}$ of April 1948, the new Constitution was decided, by which the citizens' rights and liberties were not guaranteed, and the private ownership was not respected any more. On the $11^{\text {th }}$ of June 1948 the Great National Assembly consequently adopted the Law 119 on the nationalization of the means of production. It was a measure taken by Romania's new Communist authorities in order to lay the foundation of socialism. Article 1 decreed subject to nationalization "all the wealth of the soil not in the property of the state at the time of entry into force of the Constitution of the Romanian People's Republic, as well as individual enterprises, societies of any type and private industrial, bank, insurance, mining, transport and telecommunications associations". Nationalized (generally without any form of compensation) were 8,894 industrial, mining, transport, banking and insurance companies, followed in November 1948 by 383 cinemas and medical-sanitary facilities. By 1950, the measure was applied to chemical enterprises, pharmacies and remaining economic entities ${ }^{2}$.

After the conquering of power by the communists and the proclamation of the People's Republic of Romania, the Communist Party

\footnotetext{
${ }^{1}$ Dennis Deletant, "România sub regimul comunist (decembrie 1947- decembrie 1989)", in Mihai BĂRBUlescu, et alii, Istoria României, București, Corint, 2004, p. 407-423.

2 Ghiță Ionescu, Comunismul în România, Rom. transl. by Ion Stanciu, București, Litera, 1944, p. 187-188.
} 
started a terror in a systematic manner against all political opponents proper or imaginary. The phenomenon includes all Romanian society, because 'people's enemies' emanated from the bourgeoisie, from among factory workers and peasants. The purpose of the communist carceral system was the extermination or spiritual destruction of political prisoners. This purpose was achieved by these methods: poor living conditions in prisons, lack of hygiene, starvation, torture, guardian brutality and forced labor. There is an official written record in the archive of the Central Committee where the inhuman methods used for the interogation of political prisoners are specified:

1. beating, prolonged malnutrition with the aim of getting denunciation or to turn into an informer;

2. they bring pressure to bear upon the political prisoner in order to declare what they were forced to;

3. they falsified the declaration for the political prisoner and used forged letters in order to tear a confession from prisoners;

4. forcing the prisoner to sign false confessions ${ }^{3}$.

The submission of society by the communists led to remove from it the most important categories: elites (political, military, clerical) and students, that was "the binding generation between the old society and the future, in order that the new generations should be grown up and manipulated by the regime without having the guidance of the models from the past" 4 . With this purpose in mind, the purge of the Romanian Academy took place. Under the protection of the Bolshevik tanks, on the $7^{\text {th }}$ of June 1946 Petru Groza requested to put certain members of the Academy out of the way. The first victims were Nichifor Crainic and Petre P. Panaitescu, followed by others members, such as the philosopher Ion Petrovici - professor and former minister. All the academics were purged. Hundreds of the academic staff in universities all over the country lost their positions under the accusations of being members of the Legionnaire Movement, or of being collaborators of the Antonescu

3 Marius OpREA, "Securitatea şi moştenirea sa", in Ruxandra CESEREANU, (coord.), Comunism și represiune în România. Istoria tematică a unui fratricid național, Iaşi, Polirom, 2006, p. 31.

${ }^{4}$ Alin MureșAn, Pitești. Cronica unei sinucideri asistate, Institutul de Investigare a Crimelor Comunismului și Memoria Exilului Românesc, Iași, Polirom, 2010², p. 17. 
ARS LITURGICA. From the Image of Glory to the Images of the Idols of Modernity regime. Under these circumstances the philosophers Ion Petrovici and Nicolae Bagdasar, the sociologist and political scientist Dumitru Drăghicescu - that eventually committed suicide, theology professor and writer Nichifor Crainic and many other Romanian scholars were dismissed ${ }^{5}$.

For the communist leaders and for their soviet mentors, the students were the greatest danger. It was due to the legionnaire ideas, with national and Christian character, that were disseminated amongst them. Communist leaders in Bucharest (such as the sinister Ana Pauker, Teohari Georgescu, Alexandru Nicolski - alias Boris Grünberg, Iosif Chishinevski and Gheorghe Pintilie - alias Timofei Bodnarenko) staked on the fact that the students were vulnerable, they were easier to manipulate and to be influenced, so they might better adapt to the new regime. The adaptation process was to take place in prison, where the most grim and inhuman constraint methods could be used, whose aim were the destruction of the human person and transforming the individual into an automaton obedient to the communist regime - the so called 'new man'. To this purpose, during the night of 14/15 of May 1948, thousands of pupils and students that were on the lists of the Directorate of the Police and General Safety as legionnaires or as having sympathy for their ideas were arrested. It was a great action that took place at the same time in all great towns and in the countryside. The order was given by Teohari Georgescu on the $13^{\text {th }}$ of May $1948^{6}$. According to some testimonies from that time, the arrests were made by teams of three members, led by an agent of the Directorate of the Police and General Safety who had received a sealed envelope that should not be opened before leaving for the mission, and that contained the names of the people to be arrested. On that "communist night of Saint Bartholomew" the victims of the 'reeducation' process that took place in Romanian Gulag were gathered ${ }^{7}$.

${ }^{5}$ Constantin RĂDUlescu-Motru, Revizuiri și adăugiri: 1946, vol. IV, București, Floarea Darurilor, 1999, p. 217.

${ }^{6}$ Constantin I. Stan, Crucea reeducării. O istorie a «reeducărilor» în temnițele comuniste din România (1958-1964), București, Cristiana, 2010, p. 22-23.

7 Gabriel STĂNESCU (ed.), Dumnezeu m-a salvat din Iad! O mărturie cutremurătoare: reeducarea prin tortură la Pitești, Gherla, Canal. Convorbiri cu Traian Popescu, București, Criterion, 2008, p. 18. 


\section{The First Attempts of Reeducation in Suceava Prison}

At Suceava was the largest prison in Moldova. It was set up in a former military fort. The Directorate of the Police and General Safety (and then the State Security - created on the $10^{\text {th }}$ of July 1948) established there their interrogation offices, as well as the court hall and numerous detention cells that could host hundreds of arrested people. There were incarcerated mostly students, especially from Moldova, who studied at the faculties of Law, Medicine and Literature in Iași. During the year 1949 the old guardians were replaced with new staff, ideologically and politically indoctrinated, very brutal, but without special training. The incarcerated students were investigated at any hour, and the treatment was very bitter. The screeches and the bawls of the tortured were heard by the others internees, this aiming to intimidate them. The living conditions were very hard to bear: humidity, lack of sun light, lack of personal hygienic conditions, and the psychological terror in the presence of some interogators, well known for their sadism and cruelty. People of this kind were the commissar Alexandru Pompilian and Fischer - a merchant turned police officer over night. Other staff that led the interogations and ordered tortures were: commissars Ioan Aramă, Ştefan Bălăceanu, Octavian Blehan, L. Cernenschi / Ciornenschi, Berheci, Iosif Davidovici and Șnițer / Schnitzer, security colonel Isac / Ioan Popic and Israil Rukenstein. These were the general life conditions that hundreds of young internees, without a life experience - they were between 19 and 25 year old -, had to go through. The situation at Suceava was very well known by the Security and it was led by the head of the Ministry of Internal Affairs. The scheme was set up at the initiative of General Alexandru Nicolski, brought by the Soviets, as we mentioned above ${ }^{8}$.

At Suceava, in November 1948 "the Organization for Detainees with Communist Beliefs" (O. D. C. B.) was founded, having the purpose of the "peaceful" reeducation of the students. The structure of this was modeled based on the Communist Party, and all the supporters of the reeducation were registered. The main leaders of this organization were Alexandru Bogdanovici and Eugen Țurcanu, other members of the

${ }^{8}$ Dan LuCinescu, Jertfa (Transfigurării), Iași, Fides, 1997, p. 71-73. 
ARS LITURGICA. From the Image of Glory to the Images of the Idols of Modernity reeducation committee being Ștefan Moravschi, Ion Bole, Ion Negură, Gheorghe Caziuc. We must write a few notes about the main leaders of O. D. C. B.: Alexandru Bogdanovici had a history of legionnaire activity: first arrested in 1943, he is sentenced to 6 years of correctional detention; the second sentence - three years - is received in 1945, for taking part in the Ciucaș mountain resistance. On his last arrest, in 1948, he was practically the leader of the Iron Guard Student Community (Cross Brotherhood) in Iași. Eugen Țurcanu was arrested on 3 July 1948, after he was reported taking part in Iron Guard meetings and as a member of the Câmpulung (in Moldova) Iron Guard Brotherhood. After 1944 he joined the Communist Party and tried to hide his past legionnaire activity. That is why he was arrested ${ }^{9}$. At the beginning, the political officers did not agree for this organization to copy the Communist party structure. In fact, it was finally forbidden. The leadership of the O. D. C. B. made important efforts in order to extend the process throughout the prison, but "the adhesion to O. D. C. B. was extraordinary small, insignificant, all the other detainees (...) opposing strongly this action" 10 .

O. D. C. B. activities were: conferences on Soviet Union, studies on history official papers of the Communist Party in the Soviet Union, studies of communist doctrine, debates; they used to combat the decadent and reactionary capitalism and condemn the American expansionist imperialism; they even appealed to the Romanian Workers' Party to sustain the organization ${ }^{11}$. From the notes of one student who knew this first stage of non-violent re-education, we find out that at meetings led by O. D. C. B. members, they sang communist songs ${ }^{12}$.

The main character of this period was Alexandru Bogdanovici. He was the leader of the legionary group named 'University', in Iași; due to

9 Marcel Petrișor, Memorii, vol. II (Secretul Fortului 13. Reeducări și execuții), Iași, Timpul, 1994, p. 107.

${ }^{10}$ Mircea StĂNeSCU, „Istorie și memorie a reeducării”, in Ilie POPA (editor), Experimentul Pitești - Reeducarea prin tortură, vol. I, Pitești, Fundația Culturală „Memoria”, 2003, p. 95; Gabriel STĂNESCU (editor), Dumnezeu m-a salvat din Iad! O mărturie cutremurătoare: reeducarea prin tortură la Pitești, Gherla, Canal. Convorbiri cu Traian Popescu, București, Criterion, 2008, p. 28.

11 Mircea STĂnESCU (editor), Organismele politice românești (1948-1965). Documente privind instituțiile și practicile, București, Vremea, 2003, p. 301-302.

12 Victor LeAHU, Starțun. Intre temniță și vecie, Roman, Mușatina, 2006, p. 220. 
this fact, the communists condemned him to 18 years of hard work. At his father's urge, who eventually became a sub-prefect, and also with the hope for a penance reduction, he accepted to collaborate with the prison authorities, especially with colonel Isac/Ion Popic. Although Bogdanovici was an intelligent person and a good speaker, his action did not have a great impact ${ }^{13}$. The activity of Bogdanovici and his acolytes intensified at the beginning of the year 1949, which was immediately after very hard adjudications were sentenced, at the faked trials. Eugen T,urcanu, Alexandru Mărtinuş, Alexandru Popa 'Țanu' and others were also reeducated. But the lack of success of O.D.C.B. led to rivalry, especially between Alexandru Bogdanovici and Eugen T,urcanu. Security preferred Țurcanu for future re-education actions and abandoned Bogdanovici, as the latter did not seem fully devoted. So, within the first group of prisoners transferred to Pitești, on the $22^{\text {nd }}$ of April 1949, there were Turcanu and his acolytes. Bogdanovici belonged to the last group, transferred on the $5^{\text {th }}$ of Noember $1949^{14}$. At Pitești, under Eugen Țurcanu's leadership, the terrible drama of re-education by torture started.

\section{2. 'Re-education' in Pitești Penitentiary}

The Pitești penitentiary is located in the northern part of the city, close to the Pitești-Nord railway station. It was in a secluded area, far from any housing. So, the prison was fit for tortures, as the sounds could not be heard by anybody. It was created in 1923, as a remand for common law prisoners. During the autumn of the year 1948, General Penitenciary Directorate decided the prison's reconversion in accordance with sociopolitical criteria. Thus, Pitești prison was assigned to arrested students. The first groups of students were transferred from Jilava and Cluj at the end of the year 1948; at the beginning of 1949 the prisoners from Suceava were brought here ${ }^{15}$. Between 1937 and 1942, a new T shaped building

13 Neculai PoPA, Coborârea în iad. Amintiri din închisorile României comuniste, București, Vremea, 1999, p. 59.

${ }^{14}$ AlinMureșAn,„Acțiunea Pitești (1949-1951) - chintesența regimului communist”, in DumitruLĂCĂTuȘu /Alin MureșEANu (editors), Casa terorii. Documente privind penitenciarul Pitești (1947-1977), Iași, Polirom, 2008, p. 18-21.

15 Dumitru LĂCĂTUȘU, „Penitenciarul Pitești: istoric și regim concentraționar”, in Casa terorii. Documente privind penitenciarul Pitești (1947-1977), Iași, Polirom, 2008, p. 46-49. 
was erected. It had basement, ground floor and two storeys with 96 cells, situated on the two sides of a concrete corridor. The basement cells had concrete pavement, the others had timber flooring. The total capacity was 700 up to 800 places. The edifice and the 5 interior court yards were surrounded by a brick wall about 3 meters tall and 30 centimeters thick, with 6 guard turrets ${ }^{16}$. Every cell had rows of overlapped beds, along the walls, and two buckets, one for water and the other for personal necessities. These buckets were emptied two times a day, in the morning and in the evening, when the prisoners were taken to the toilet ${ }^{17}$.

The students were divided into four categories. The first category comprised prisoners incarcerated without judgement; they could have waited for their judicial trial up to 7 years. The second category comprised the students convicted for minor delicts, from suspicion, to omitting the denunciation or favorising misdemeanor, of course, a political one. The third category comprised the most students 'guilty' of 'conspiracy against social order'; they were sentenced to 8 up to 15 years in penal servitude. The last category comprised the outstanding representatives of the students that had a strong and active influence over their fellows; they were sentenced to 10 up to 25 years of forced labor. The purpose of this division was to separate the students convicted for minor delicts, considered to be more susceptible to yield under pressure and to accept the reeducation process ${ }^{18}$.

We noted above that Eugen T,urcanu was already known to The Security, and he eventually became an informant of the Operational Bureau, being supported by Iosif Nemes, the head of the Operational Service. In the Pitești prison, he gained the trust of the prison warden, Alexandru Dumitrescu. Another important support for Țurcanu's plan was political officer Ioan Marina, who was sent to Pitești by Nemeș. Țurcanu became a reliable person for Marina, and by this, Țurcanu and the detainees gathered around him profited from some facilities: better

16 Alin MureșAn, „Acțiunea Pitești (1949-1951) - chintesența regimului communist”, in Dumitru LĂCĂTușu / Alin MureșEAnu (editori), Casa terorii. Documente privind penitenciarul Pitești (1947-1977), Iași, Polirom, 2008, p. 36-37.

${ }^{17}$ Dumitru BordeIANU, Mărturisiri din mlaștina disperării, București, Scara, 2001², p. 3033.

18 Dumitru BACU, Pitești. Centru de reeducare studențească, București, Christiana, 2011, p. $59-60$. 
food, free acces in prison, and the right for T,urcanu to appoint only his men for the guard duty. Gradualy T,urcanu became a detainee with 'importance', having conversations with Marina and Nemeș. From their collaboration was initiated a violent reeducation program, at the direct proposal of Țurcanu and Marina.

Being sustained by the prison staff, during summer and autumn of the year 1949, T,urcanu observed and identified the students' leaders and disposed their isolation. During this period, the resistance of the future victims was weakened by a harsher regime: starving, physical misery and isolation. At this time, Turcanu and the agressors he led were physically strenghting ${ }^{19}$.

According to some researchers, the experiment of reeducation by torture started in Pitești on the morning of the $6^{\text {th }}$ of December, the feast of Saint Nicholas ${ }^{20}$. Alin Mureșan wrote that everything started around the $25^{\text {th }}$ of November $1949^{21}$. First they used a strong thrashing. The blows and strokes were unmerciful, yet their efficiency was due to the victims' surprise when they noticed the brutal intervention of the guardians and of the prison director in support of Țurcanu's fighting group. This made the detainees understand the seriousness of their situation: they were to be tortured by their prison mates, and the stage direction was made by the authorities. One of the beaten prisoners, Pafnutie 'Nuti' Pătrășcanu, yielded and aligned himself on the side of Țurcanu. Subsequently, the violences took place in the frightening 'chamber 4 - hospital'. In the beginning, that cell hosted the prison infirmary, but, since the room was large, Țurcanu used it to bring into force his method of torture on larger detainee groups. The first such large group was tortured during the Christmas of 1949, Alexandru Bogdanovici being among them, because he arrived there from Suceava. At that time the warden and the guardians also supported Turcanu's fighting group. The young detainees were terribly beaten. They were hit in all the parts of the body, with fists, with feet, with clubs and broom handles. After the students were so beaten, the agressors jumbled their victims up together,

19 Gheorghe ANDREICA, Reeducările comuniste. Vol. I, Eugen Țurcanu, rușinea speciei umane, Constanța, Ex Ponto, 2077, p. 120-124.

${ }^{20}$ Virgil IERUnCA, Fenomenul Pitești, Iași, Humanitas, 1991, p. 29.

21 Alin Mureșan, Pitești. Cronica unei sinucideri asistate, Institutul de Investigare a Crimelor Comunismului și Memoria Exilului Românesc, Iași, Polirom, 2010, p. 42. 
like a pyramid of human suplice and cruelty. The students that were beneath had to endure the weight from above, and because of that some of them passed out. After the pyramid was erected, the beatings started once more individually, beginning with the victims from the top. In the following days, more tortures were added: the 'reeducation' victims were forced to make hundreds of genuflexions, lunges, jumps and somersaults; the students were banged with their heads against the walls, they were hit with the heel or with the knee in their liver; they were forced to ingest excrements and urine, to lick the toilet, and to perform other repulsive acts. After all these torments, at other moments of the day, the detainees had to endure other tortures: they were forced to stay in tormenting positions for hours or for days, they were not allowed to sleep, or to use the toilet when they needed, they were humiliated during lunch being forced to eat lying on their belly without using their hands especially when the food was very hot. The torture was therefore continuous, the students being physically and psychologicaly attacked, because everything was carried out in sight of all. We add that the obligation to witness their comrades' torture, or even to torture their own comrades, was an additional torment, as difficult, or even more difficult to endure than their own torture.

The terrifying aspect of the 'reeducation' process was this continuous torturing of the detainees by other detainees - which, by this, were substituting the interogators, but also because the victims were forced to denounce their own anticommunist activity, as well as their relatives, friends and colleagues of prison. The denunciations were made firstly verbal, then were written, 'on one's own' ${ }^{22}$. Some of the tortured ones tried to avoid the implication of anticommunist leaders, by declaring imaginary actions that involved some officials of the Communist Party ${ }^{23}$.

It is now the moment to describe the 'Free education' process that took place involving Turcanu and his thugs. Most authors who studied this terrible phenomenon, as well as the writers of memoirs, thus described the four steps of the process:

22 Dumitru BACU, Pitești. Centru de reeducare studențească, București, Christiana, 2011, p. 79-85.

23 Mihai Timaru, Memorial din cotul Carpaţilor, Institutul Național pentru Studiul Totalitarismului, București, 2005, p. 89-92. 
1. The outer exposure. The detainee was forced to confess his faithfulness to the Communist Party, to reveal everything that he had not confessed at previous inquiries: his connections outside the prison, the accomplices that had helped him, and any information that could interest T,urcanu or the political officers. The declaration was made verbaly at first, was verified by T, Tutcanu himself, then it was written down, signed and sent to Bucharest. It seems that, during the outer exposure, the Security gathered more information about anticommunist activities than during ordinary interrogations.

2. The inner exposure. The tortured victim was forced to 'denounce' all the people that had helped him hold out during detention: detainees that had heartened him, or had advised him to prudence, a more compliant interrogator, or a kind guardian. During this step, the administration also gathered information that enabled them to dismiss clement guardians.

3. The moral and publical exposure. By this step, the process of internal destruction of the detainee, the deconstruction of his personality, had started. At this stage, that led to mind pathology, the student had to trample underfoot everything he held as sacred: family, religious faith, education, friends, his life, moral and political models, etc. The students that came to this moment were living a terrible conscience drama, because they had to accuse their parents, the Church, their teachers. Mostly, Turcanu himself and the other torturers were pleased to hear that the mothers or sisters of the tortured were described as immoral persons, that the fathers were sadistic or immoral as well, and that they had allegedly taken part in sexual orgies and incest etc. Amongst the detainees there were priests' sons and young men from the countryside, for whom the Church was the most sacred. They were forced to describe in detail imaginary dirty scenes in which their mother or their father would have participated. A son of a priest had to declare that his father would have profaned the holy altar by immoral actions, that he was a liar and a charlatan that cheated the faithfull. When T,urcanu was satisfied with the horrors he had heard, and considered that the soul demolition of the student had come to a climax, he declared the victim worthy to join the O. D. C. B. We remind that during all these steps the torture was permanent. The victim could not escape torture, no matter how base were the things he had invented. He could only limit the time of his sufferings. At this stage of his personality destruction, the student was brought to the point of 'self breaking', that meant to write an autobiography 
ARS LITURGICA. From the Image of Glory to the Images of the Idols of Modernity

in which he denigrated himself, publicly presenting himself as a criminal and an immoral young man from his early childhood.

4. Finally, the 'reeducated' detainee, spiritually disfigured, had to lead the 'reeducation' process of his best friend in prison, whom he had to torture with his own hands. So he became an agent of 'reeducation' and the executioner of his best friend ${ }^{24}$.

Because most detainees were people educated in the orthodox Christian faith, and with strong nationalist convictions, i.e. they were educated to love their country and their people, certainly they were in an irreducible opposition to communist doctrine. The same situation had the Theology students, who were the favorite victims of the aggressor teams. T,urcanu and his men had a special pleasure to ridicule the Christian faith, everything about our Lord and the Virgin Mary. The victims were forced to publicly acuse Christian education they had received in their family and in the Church, due to which they were in prison. Theology students and those that put forth their Christian faith were ironically named 'mystical' persons, and became main characters in blasphemous plays staged by Țurcanu himself on the occasions of Christmas and Easter. During those feasts, Theology students were dressed in 'cassocks' and 'stoles', which were befouled with excrements. They had to perform the Eucharist with excrements and urine. We cannot describe here the antichristian and grotesque performance related by eyewitnesses. We just specify the forced gibing of the Decalogue, the singing of church anthems using obscene texts, the pantomime of sexual orgies with Biblical characters, in a nut-shell, the profanation of the orthodox faith and of church services. On the top of the horror and of murders was the staging of the Crucifixion, the victim being a young man who had totally refused any collaboration in 'reeducation'. He was crucified on the wall, and then he was murdered by Țurcanu himself. In this case it is significant to note that through the peep hole "an inspector surrounded by a powerfull guard' were looking at that 'performance" 25 .

24 Ioan IANOLIDE, Intoarcerea la Hristos. Document pentru o lume nouă, Mănăstirea Diaconești, București, Christiana, 2006, p. 96-99.

25 Viorel GheOrghiță, Et ego. Sărata. Pitești-Gherla-Aiud. Scurtă istorie a devenirii mele, Timișoara, Marineasa, 1994, p. 164-165; Ioan IANOLIDE, Intoarcerea la Hristos. Document pentru o lume nouă, Mănăstirea Diaconești, București, Christiana, 2006, p. 270-275. 
It is difficult to provide an average number of the detainees who died because of tortures. The historian Mircea Stănescu, who studied the matter, established 41 murdered by tortures. However, the causes of death were not always correctly recorded, so the number of deaths because of beatings and tortures might be greater ${ }^{26}$. This might be the meaning of Leonard Kirschen's confession, in his memoirs book, that the Pitești penitentiary could only be left for three destinations: Bucharest for new interrogations, hospital, or cemetery ${ }^{27}$.

The thrashings ceased in May 1951, for reasons still unknown. However, the attempts at communist indoctrination went on till the end of July 1951. Only then T,urcanu and his men were transferred to other cells. T,urcanu confessed to some of his collaborators that he would commit suicide if 'exposure' were forbidden. He added that his actions could end only in success or in death. From his confession we understand that he was aware of his actions. The students in Pitești prison were taken to Gherla, as the communist regime wanted that the re-education by torture should be spread. At the end of 1951, the first group of students left for Gherla. Eugen T,urcanu was among them, too. Torture and beatings were applied in the other penitentiaries as well; here they tried to 'export' the Pitești phenomenon: to Brașov (between March 1950 and February 1951), Gherla (between June 1950 and December 1951), Târgşor (between August 1949 and November 1950), Târgu Ocna (between may 1950 and May 1951), Peninsula (between June 1950 and July 1951). We may consider that the penitentiary torture system ended in the autum 1951, maybe after the incendiary statements made by a detainee, Vintilă Vais, tortured at Gherla in cell 99 . He was smart enough to say that tortionary detainees, before being arrested, had belonged to the Legionaire Movement or Iron Guard, and that the inhuman tortures they applied would lead to the discreditation of the communist regime. An important role in this matter had the cold-blooded murder, in the Peninsula prison, of doctor Ion Simionescu, a former state secretary, before the communist

${ }^{26}$ Mircea STĂNESCU, „Asupra numărului morților din reeducarea de tip Pitești (1949-1951). O reevaluare”, in Ilie POPA (coord.), "Experimentul Pitești”. Conference Proceedings. Comunicări prezentate la Simpozionul „Experimentul Pitești - Reeducarea prin tortură”. Cultura, tineretul, și educația în regimurile dictatoriale comuniste, ediția a VII-a, Pitești, 57 octombrie 2007, Pitești, Fundația Culturală "Memoria”, Filiala Argeș, 2008, p. 115-158.

${ }^{27}$ Leonard KIRSCHEN, Deținut al justiției roșii, București, Enciclopedică, 2002, p. 252-253. 
regime. The news was learned abroad, and the Communist Party was in trouble. Only then the regime decided to suppress the penitentiary torture system. After this supression followed the inquiry and the punishing of the people involved. Amongst them were Eugen T,urcanu, some of his men, and the prison staff that consciously supported such horrific actions $^{28}$.

\section{Conclusions}

Among all the countries under Soviet control, in Romania took place the most horrific and the sickest experience of 're-education' by torture, firstly in Pitești penitentiary. Hundreds of beautiful, pure, highly trained and well educated young men suffered a process of soul mutilation and dehumanization, by means that were never used anywhere else. At Pitești penitentiary, physical and psychological torture reached the climax of demential cruelty. So, it is not surprising that under this situation some of the 'reeducated' detainees became in their turn 'reeducators'. Their dehumanization and despair reached such high levels, that they were able to denounce the kindly guardians. After unimaginable atrocities in Pitești penitenciary, a mutation of the human psychic occurred. A new 'human' type was created, in fact a monster looking like a human being, who was meant to be "an enigma and a terror for the detainees in penitentiaries chosen for the extension of that experience, because the «island» Pitești was meant to become the Pitești «Archipelago»" 29 .

The barrister Petre Pandrea, himself a victim of the communist «gulag» in Romania, stated on record that the methods used for torture "had to create a psychological shock, a radical inner transformation through which the detainee, student or intellectual, by frightening, suddenly and for good, became from a reactionary the best MarxistLeninist. The 'pedagogical method' of Pitești had as an ideative nucleus the «explosion» method of Macarenko. This method was applied in Romania during the 1948-1952 period, the hateful time when the odious

28 Alin Mureșan, Pitești. Cronica unei sinucideri asistate, Institutul de Investigare a Crimelor Comunismului și Memoria Exilului Românesc, Iași, Polirom, 2010², p. 78125.

29 Virgil IeruncA, Fenomenul Pitești, Iași, Humanitas, 1991, p. 49. 
Stalinist Ana Pauker was in power"30. Another eyewitness of the cruelties in the Pitești 'archipelago', Ioan Ianolide, wrote that "reeducation was the conceptual fruit of this philo-Soviet activist (i.e. Ana Pauker), who wanted to exterminate the enemies of communism by force, while Gheorghiu-Dej wanted to achieve this by hard labour. The prisons, the concentration camps, and the «reeducation» in the '50s, were the expression of the crime and hatred policy of Ana Pauker"'31.

The torturers based their actions on shock, on the psychological destruction of victims who could not react at all. Another victim of this process, Octavian Voinea, underlined that "The fear, the perplexity and the surprise were so high, the shock was so strong, that some detainees collapsed in the first phase. Even if the victim did not collapse at the first stroke, the inner edifice of the person was cracked, and the man was going to break down". Octavian Voinea further brings to light the fact that the psychological effect of the first shock made the victim "incapable of any reaction. Everything is hopeless. The victim is convinced that the affair is organized in this manner. There is no escape". The author also notes that "the torturers had to submit their colleagues to huge efforts, meant to completely exhaust them physically [...]. Physical exhaustion caused psychological exhaustion. The victim has no moment for recovering himself. The reason is shaken, the will is getting dark. From the human mind all emotions vanish. The affection vanishes. The man stops reacting" 32 .

The victims suffered important psychological changes. Professor and essay-writer Ruxandra Cesereanu highlighted that "the victims were transformed into executioners, brougt to the basic level of some hybrid by methodical dehumanisation"33. The psychologist Adrian Nicolau, after a close study of the Pitești'phenomenon', discovered that, in that penitentiary, "they organized in fact an applied psychological experimental laboratory, according to scientific criteria", where the study

${ }^{30}$ Petre PANDREA, Reeducarea de la Aiud, București, Vremea, 2000, p. 90.

31 Ioan IANOLIDE, Intoarcerea la Hristos. Document pentru o lume nouă, Mănăstirea Diaconești, București, Christiana, 2006, p. 30.

32 Octavian VoINEA, Masacrarea studenților români la închisorile de la Pitești, Gherla și Aiud, București, Majadahonda, 1996, p. 42-43.

${ }^{33}$ RuxandraCESEREANu, (coord.), Comunism și represiune în România. Istoria tematică a unui fratricid național, Iași, Polirom, 2006, p. 154. 
theme was "the transformation of man into his opposite" 34 .

Ioan Ianolide, an eyewitness, made similar observations. He gave the best definition of the criminal regime in Pitești penitentiary, where the 'reeducated' torturered people had been transformed into "a miscreant individual by the terror of Marxist-Leninist reeducation, a so-called logical mechanism that decomposes the being from inside, and after that, it tries, by monstruous methods, to make up the socialist man, in fact a monster. And no-one can escape uncorrupted from the torture «shift» of Marxist-dialectical reeducation. The results of the reeducation and Marxist education are exclusively criminal, bestial, decadent and dehumanising, degrading the human nature itself"35.

\section{References}

1. ANDREICA, Gheorghe, Reeducările comuniste. Vol. I, Eugen Țurcanu, ruşinea speciei umane, Constanţa, Ex Ponto, 2077.

2. BACU, Dumitru, Pitești. Centru de reeducare studențească, București, Christiana, 2011.

3. BORDEIANU, Dumitru, Mărturisiri din mlaștina disperării, București, Scara, $2001^{2}$.

4. Cesereanu, Ruxandra (coord.), Comunism și represiune în România. Istoria tematică a unui fratricid național, Iași, Polirom, 2006.

5. Deletant, Dennis, "România sub regimul comunist (decembrie 1947decembrie 1989)", in Mihai Bărbulescu et alii, Istoria României, București, Corint, 2004, p.407-423.

6. GHEORGHiȚĂ, Viorel, Et ego. Sărata. Pitești-Gherla-Aiud. Scurtă istorie a devenirii mele, Timișoara, Marineasa, 1994.

7. IANOLIDE, Ioan, Intoarcerea la Hristos. Document pentru o lume nouă, Mănăstirea Diaconești, București, Christiana, 2006.

8. IERUNCA, Virgil, Fenomenul Pitești, Humanitas, 1991.

9. IONESCU, Ghiță, Comunismul în România, Rom. transl. by Ion Stanciu, București, Litera, 1944.

${ }^{34}$ AdrianNicolau, "Reeducarea, un experiment psihologic", in Gilles FerReul /AdrianNicolau (coord.), Violența. Aspecte psihosociale, Iași, Polirom, 2003, p. 203.

${ }^{35}$ IoanIANOLIDE, Intoarcerea la Hristos. Document pentru o lume nouă, Mănăstirea Diaconești, București, Christiana, 2006, p. 279. 
10. KIRSCHEN, Leonard, Deținut al justiției roșii, București, Enciclopedică, 2002.

11. LĂCĂTUȘU, Dumitru, "Penitenciarul Pitești: istoric și regim concentraționar", in Casa terorii. Documente privind penitenciarul Pitești (1947-1977), Iași, Polirom, 2008, p. 46-49.

12. LEAHU, Victor, Starțun. Intre temniță și vecie, Roman, Mușatina, 2006.

13. LuCINESCU, Dan, Jertfa (Transfigurări), Iași, Fides, 1997.

14. MureșAN, Alin, “Acțiunea Pitești (1949-1951) - chintesența regimului comunist", in Dumitru LĂCĂTUȘU /Alin MUREȘEAN (editors), Casa terorii. Documente privind penitenciarul Pitești (19471977), Iași, Polirom, 2008, p.18-21.

15. MureșAn, Alin, Pitești. Cronica unei sinucideri asistate, Institutul de Investigare a Crimelor Comunismului și Memoria Exilului Românesc, Iași, Polirom, 2010².

16. NiCOLAU, Adrian, "Reeducarea, un experiment psihologic", in FERREUL, Gilles / NicOlaU, Adrian (coord.), Violența. Aspecte psihosociale, Iași, Polirom, 2003, p. 203.

17. OPREA, Marius, "Securitatea și moștenirea sa", in Ruxandra Cesereanu (coord.), Comunism și represiune în România. Istoria tematică a unui fratricid național, Iași, Polirom, 2006, p. 31.

18. PandReA, Petre, Reeducarea de la Aiud, București, Vremea, 2000.

19. Petrișor, Marcel, Memorii, vol. II (Secretul Fortului 13. Reeducări și execuții), Iași, Timpul, 1994.

20. PopA, Neculai, Coborârea în iad. Amintiri din închisorile României comuniste, București, Vremea, 1999.

21. RĂDULESCU-MotRU, Constantin, Revizuiri și adăugiri: 1946, vol. IV, București, Floarea Darurilor, 1999.

22. Stan, Constantin I., Crucea reeducării. O istorie a «reeducărilor» în temnițele comuniste din România (1958-1964), București, Cristiana, 2010.

23. StĂNESCU, Gabriel (ed.), Dumnezeu m-a salvat din Iad! O mărturie cutremurătoare: reeducarea prin tortură la Pitești, Gherla, Canal. Convorbiri cu Traian Popescu, București, Criterion, 2008.

24. STĂNESCU, Mircea, "Istorie și memorie a reeducării", in Ilie POPA (editor), Experimentul Pitești - Reeducarea prin tortură, vol. I, Pitești, Fundația Culturală "Memoria", 2003, p. 95. 
25. STĂNESCU, Mircea (editor), Organismele politice românești (1948-1965). Documente privind instituțiile și practicile, București, Vremea, 2003.

26. STĂNESCU, Mircea, "Asupra numărului morților din reeducarea de tip Pitești (1949-1951). O reevaluare", in Ilie POPA (coord.), Experimentul Pitești. Conference Proceedings. Comunicări prezentate la Simpozionul "Experimentul Pitești - Reeducarea prin tortură. Cultura, tineretul, și educația în regimurile dictatoriale comuniste",ediția a VII-a, Pitești, 5-7 octombrie 2007, Fundația Culturală "Memoria", Filiala Argeș, Pitești, 2008, p.115-158.

27. Timaru, Mihai, Memorial din cotulCarpaților, București, Institutul Național pentru Studiul Totalitarismului, 2005.

28. VOINEA, Octavian, Masacrarea studenților români la închisorile de la Pitești, Gherla și Aiud, București, Majadahonda, 1996. 